\title{
Seismic Performance of Reinforced Concrete Buildings with Masonry Infill
}

\author{
Girma Zewdie Tsige*, Adil Zekaria \\ Department of Civil Engineering, Addis Ababa Institute of Technology, Addis Ababa, Ethiopia \\ Email address: \\ grmzewdie@gmail.com (G. Z. Tsige), adil.zekaria@aait.edu.et (A. Zekaria) \\ ${ }^{*}$ Corresponding author
}

\section{To cite this article:}

Girma Zewdie Tsige, Adil Zekaria. Seismic Performance of Reinforced Concrete Buildings with Masonry Infill. American Journal of Civil Engineering. Vol. 6, No. 1, 2018, pp. 24-33. doi: 10.11648/j.ajce.20180601.15

Received: September 24, 2017; Accepted: October 23, 2017; Published: January 2, 2018

\begin{abstract}
Unreinforced masonry Infills modify the behavior of framed structures under lateral loads; however, in practice, the infill stiffness is commonly ignored in frame analysis, resulting in an under-estimation of stiffness and natural frequency. The structural effect of hollow concrete block infill is generally not considered in the design of columns as well as other structural components of RC frame structures. The hollow concrete block walls have significant in-plane stiffness contributing to the stiffness of the frame against lateral load. The scope of present work was to study seismic performance of reinforced concrete buildings with masonry infill in medium rise building. The office medium rise building is analyzed for earthquake force by considering three type of structural system. i.e. Bare Frame system, partially-infilled and fully- Infilled frame system. Effectiveness of masonry wall has been studied with the help of five different models. Infills were modeled using the equivalent strut approach. Nonlinear static analyses for lateral loads were performed by using standard package ETABS, 2015 software. The comparison of these models for different earthquake response parameters like base shear vs roof displacement, Story displacement, Story shear and member forces are carried out. It is observed that the seismic demand in the bare frame is significantly large when infill stiffness is not considered, with larger displacements. This effect, however, is not found to be significant in the infilled frame systems. The results are described in detail in this paper.
\end{abstract}

Keywords: Bare Frame, Infilled Frame, Equivalent Diagonal Strut, Infill, Plastic Hinge

\section{Introduction}

Infill have been generally considered as non-structural elements, although there are codes such as the Eurocode- 8 that include rather detailed procedures for designing infilled $\mathrm{R} / \mathrm{C}$ frames, presence of infill has been ignored in most of the current seismic codes except their weight. However, even though they are considered non-structural elements the presence of infill in the reinforced concrete frames can substantially change the seismic response of buildings in certain cases producing undesirable effects (tensional effects, dangerous collapse mechanisms, soft story, variations in the vibration period, etc.) or favorable effects of increasing the seismic resistance capacity of the building.

The present practice of structural analysis is also to treat the masonry infill as non- structural element and the analysis as well as design is carried out by only using the mass but neglecting the strength and stiffness contribution of infill. Therefore, the entire lateral load is assumed to be resisted by the frame only.

Contrary to common practice, the presence of masonry infill influence the over- all behavior of structures when subjected to lateral forces. When masonry infill are considered to interact with their surrounding frames, the lateral stiffness and the lateral load capacity of the structure largely increase.

The recent advent of structural design for a particular level of earthquake performance, such as immediate post-earthquake occupancy, (termed performance based earthquake engineering), has resulted in guidelines such as ATC-40 (1996) [14], FEMA-273 (1996) [26] and FEMA-356 (2000) [13] and standards such as ASCE-41 (2006), among others. The different types of analyses described in these documents, pushover analysis comes forward because of its optimal accuracy, efficiency and ease of use.

The infill may be integral or non-integral depending on the 
connectivity of the infill to the frame. In the case of buildings under consideration, integral connection is assumed. The composite behavior of an infilled frame imparts lateral stiffness and strength to the building. The typical behavior of an infilled frame subjected to lateral load is illustrated in Figures 1 (a) and (b).

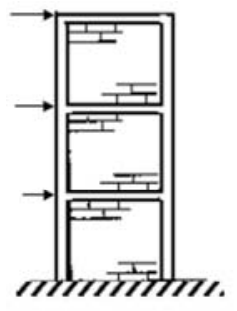

(a) Infilled frame

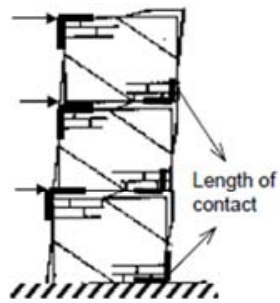

(b) Deformed shape

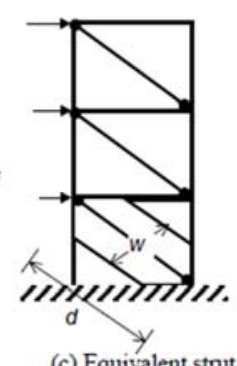

(c) Equivalent strut
Figure 1. Behavior of infilled frames (Govindan, 1986).

In this present paper five models of office building with different configuration of masonry infill are generated with the help of ETABS 2015 and effectiveness has been checked. Pushover analysis is adopted for the evaluation of the seismic response of the frames. Each frame is subjected to pushover loading case along negative $\mathrm{X}$-direction.

\section{Building Description}

Multi-storey rigid jointed frame mixed use building $\mathrm{G}+9$ (Figure 2), was selected in the seismic zone (Zone IV) of Ethiopia and designed based on the Ethiopian Building Code Standard ESEN: 2015 and European Code-2005. ETABS 2015 was used for the analysis and design of the building by modeling as a 3-D space frame system.

Seismic performance is predicted by using performance based analysis of simulation models of bare and infilled non ductile RC frame buildings with different arrangement of masonry wall. The structure will be assumed to be new, with no existing infill damage.

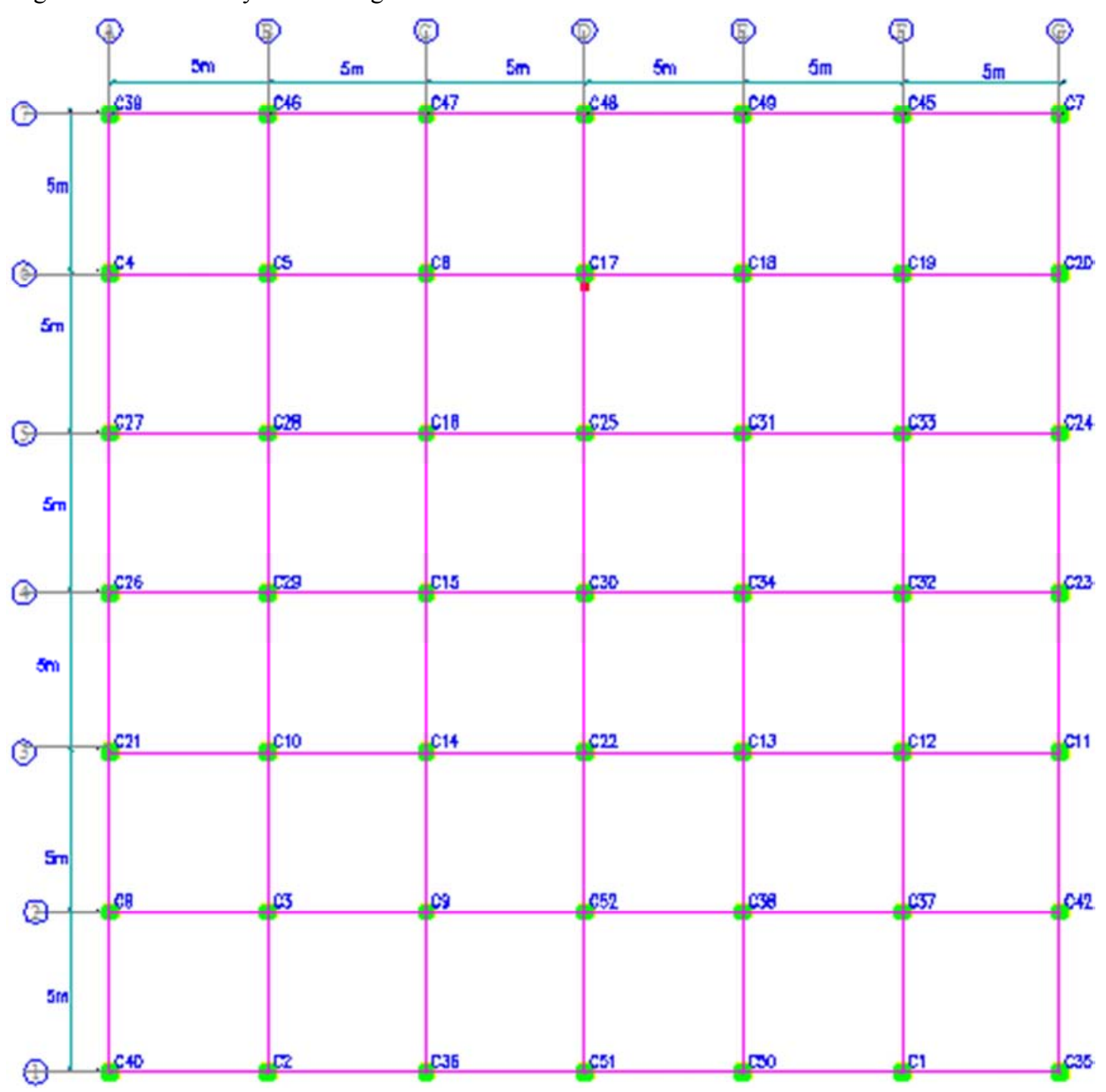

Figure 2. Typical building plan. 


\section{Building Data}

1. Type of structure $=$ Multi-storey rigid jointed frame

2. Layout $=$ as shown in figure 2

3. Zone $=\mathrm{IV}$

4. Importance Factor $=1$

5. Soil Condition $=$ hard

6. Number of stories $=$ Ten $(\mathrm{G}+9)$

7. Height of Building $=30 \mathrm{~m}$

8. Floor to floor height $=3 \mathrm{~m}$

9. External wall thickness $=20 \mathrm{~cm}$

10. Internal wall thickness $=15 \mathrm{~cm}$

11. Depth of the floor $\mathrm{slab}=15 \mathrm{~cm}$

12. depth of roof $s l a b=12 \mathrm{~cm}$

13. Size of all columns $=70 \times 70 \mathrm{~cm}$

14. Size of all beams $=70 \times 40 \mathrm{~cm}$

15. Door opening size $=100 \times 200 \mathrm{~cm}$

16. Window opening size $=200 \times 120 \mathrm{~cm}$

\section{Structural Modeling and Analysis}

To understand the effect of masonry wall in reinforced concrete frame, with a total of five models are developed and pushover analysis has been made in standard computer program ETABS2015. In this particular study pushover loading case along negative $\mathrm{X}$-axis is considered to study seismic performance of all models. Since the out of plane effect is not studied in this paper, only the equivalent strut along $\mathrm{X}$-axis are considered to study the in plane effect and masonry walls along Y-axis are not considered in all models. From this different condition, all models are identified by their names which are given below.

\subsection{Different Arrangement of the Building Models}

To understand the effect of masonry wall in reinforced concrete frame, with a total of five models are developed and pushover analysis has been made in standard computer program ETABS2015. In this particular study pushover loading case along negative $\mathrm{X}$-axis is considered to study seismic performance of all models.

Model 1:- Bare reinforced concrete frame: masonry infill walls are removed from the building along all stories

Model 2:-Reinforced concrete frame with $75 \%$ of masonry wall removed from fully infilled frame

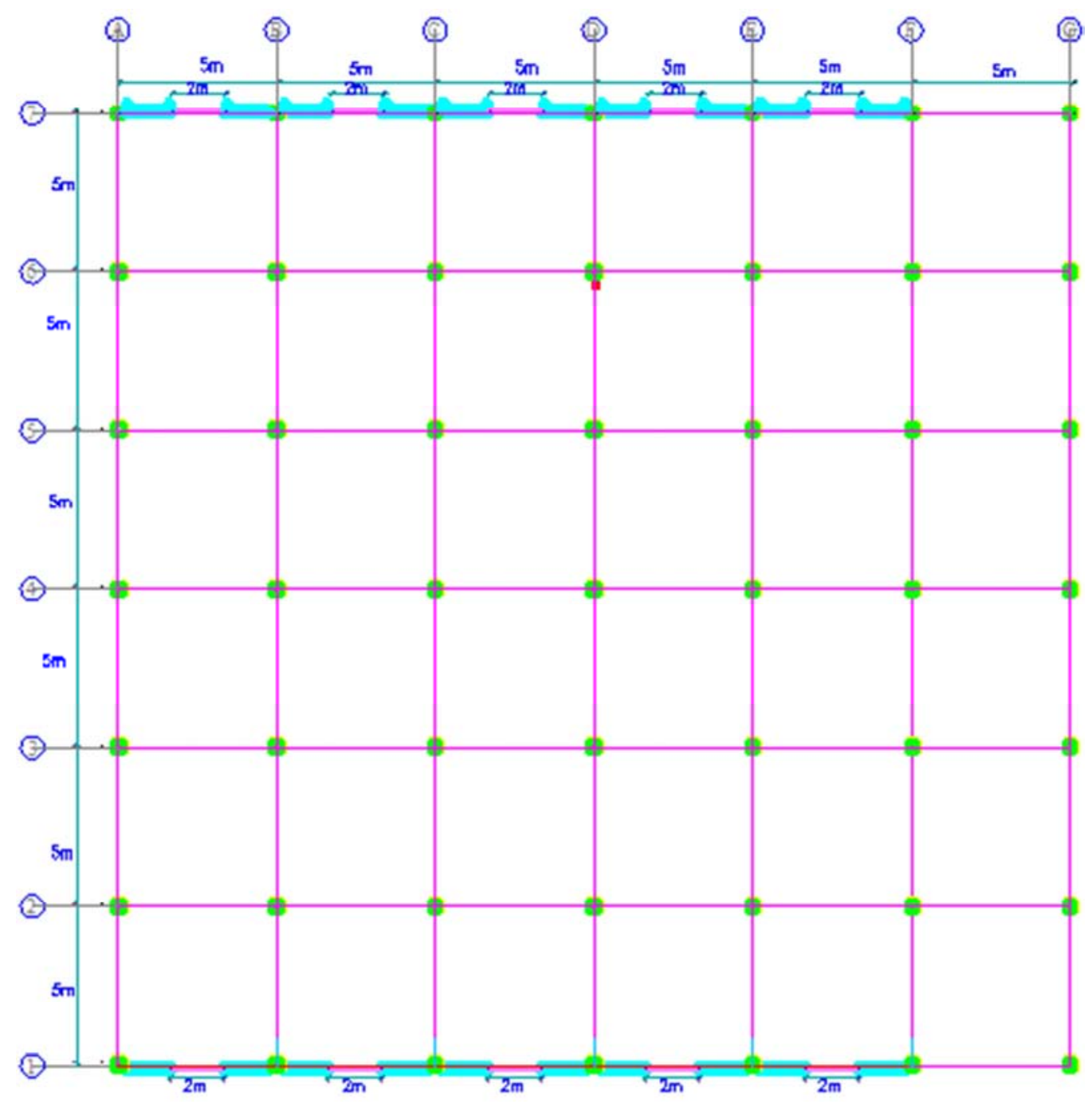

Figure 3. Plan View Model 2. 
Model 3:- Reinforced concrete frame with half of of masonry wall removed from fully infilled frame

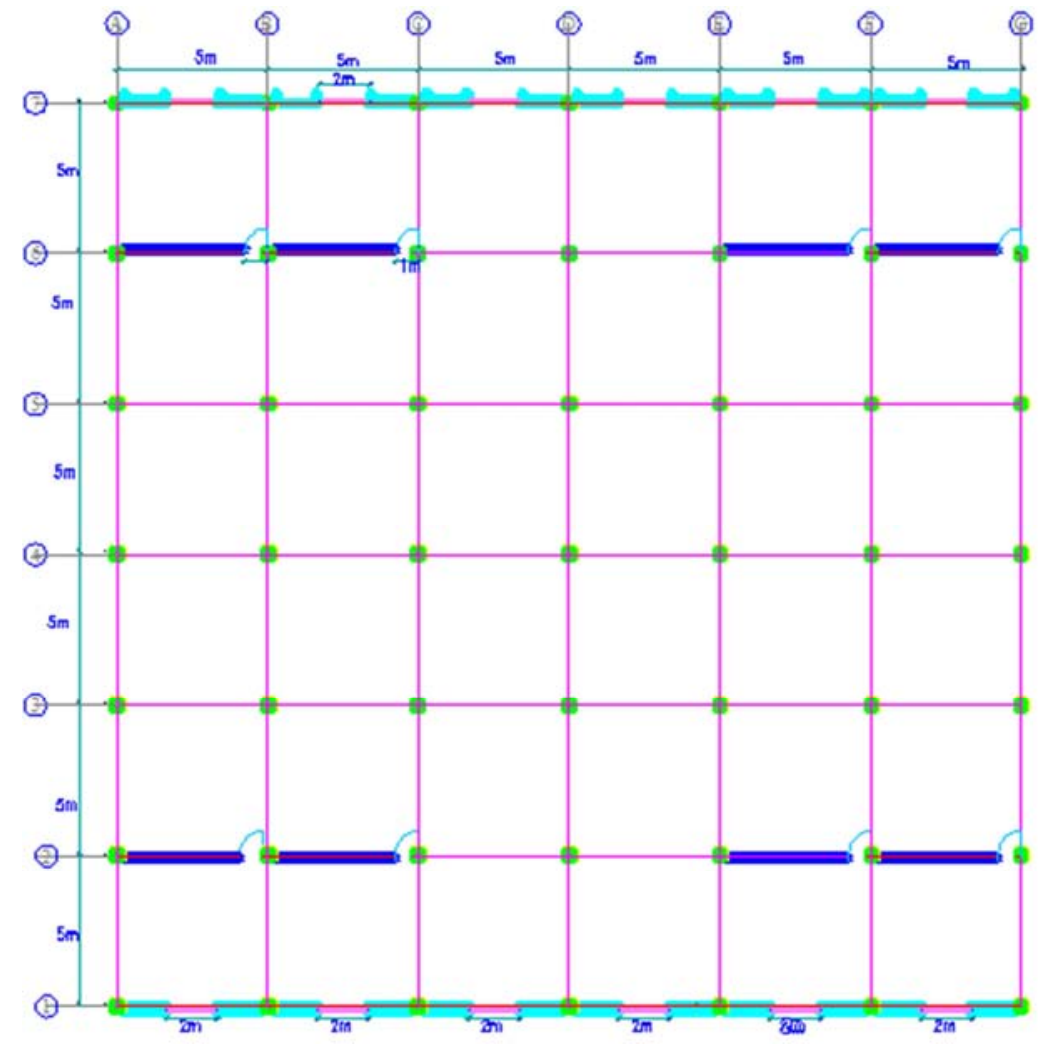

Figure 4. Plan View of Model 3.

Model 4:- Reinforced concrete frame with $25 \%$ of masonry wall removed from fully infilled frame

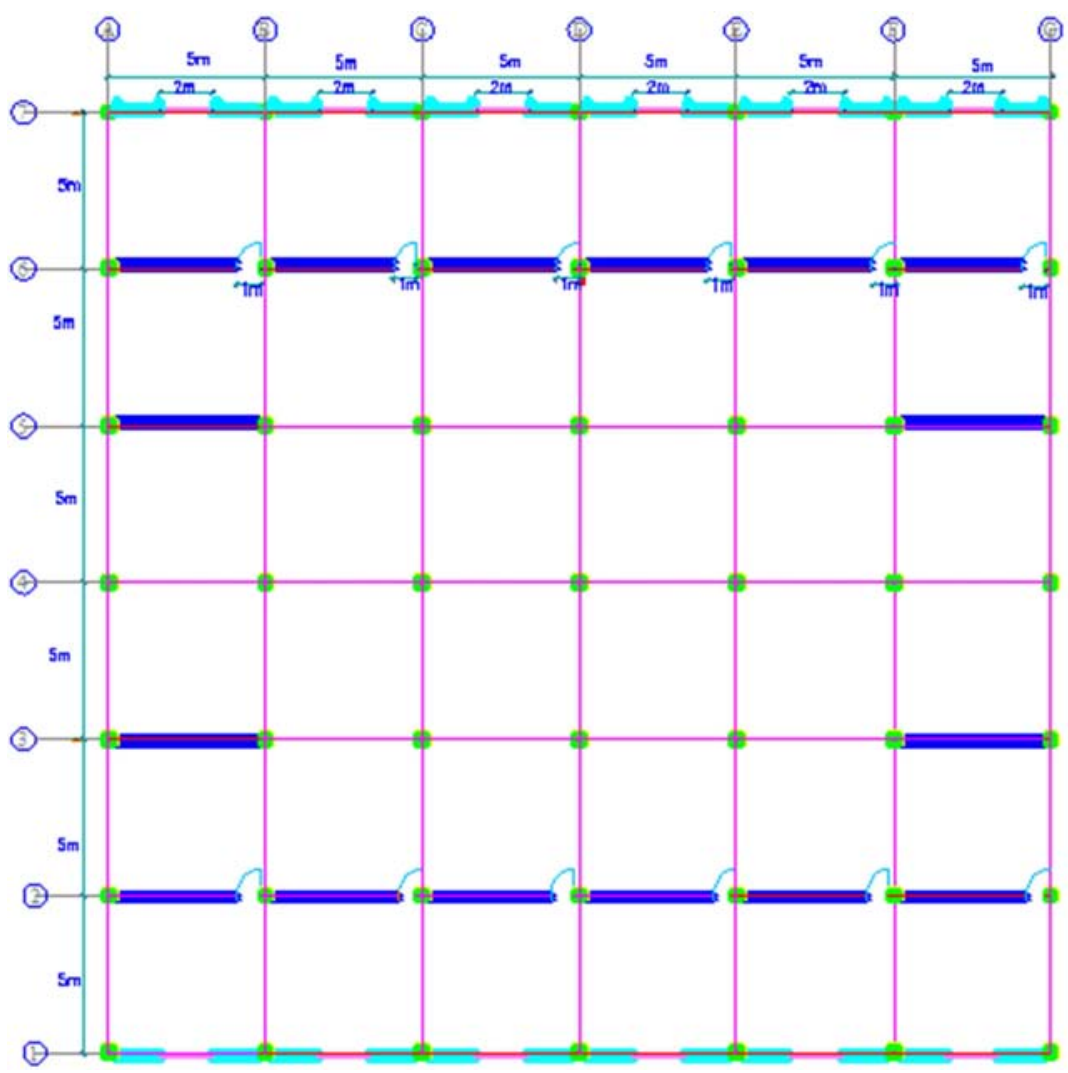

Figure 5. Plan view of Model 4. 
Model 5:- Fully infilled reinforced concrete frame (Base frame)

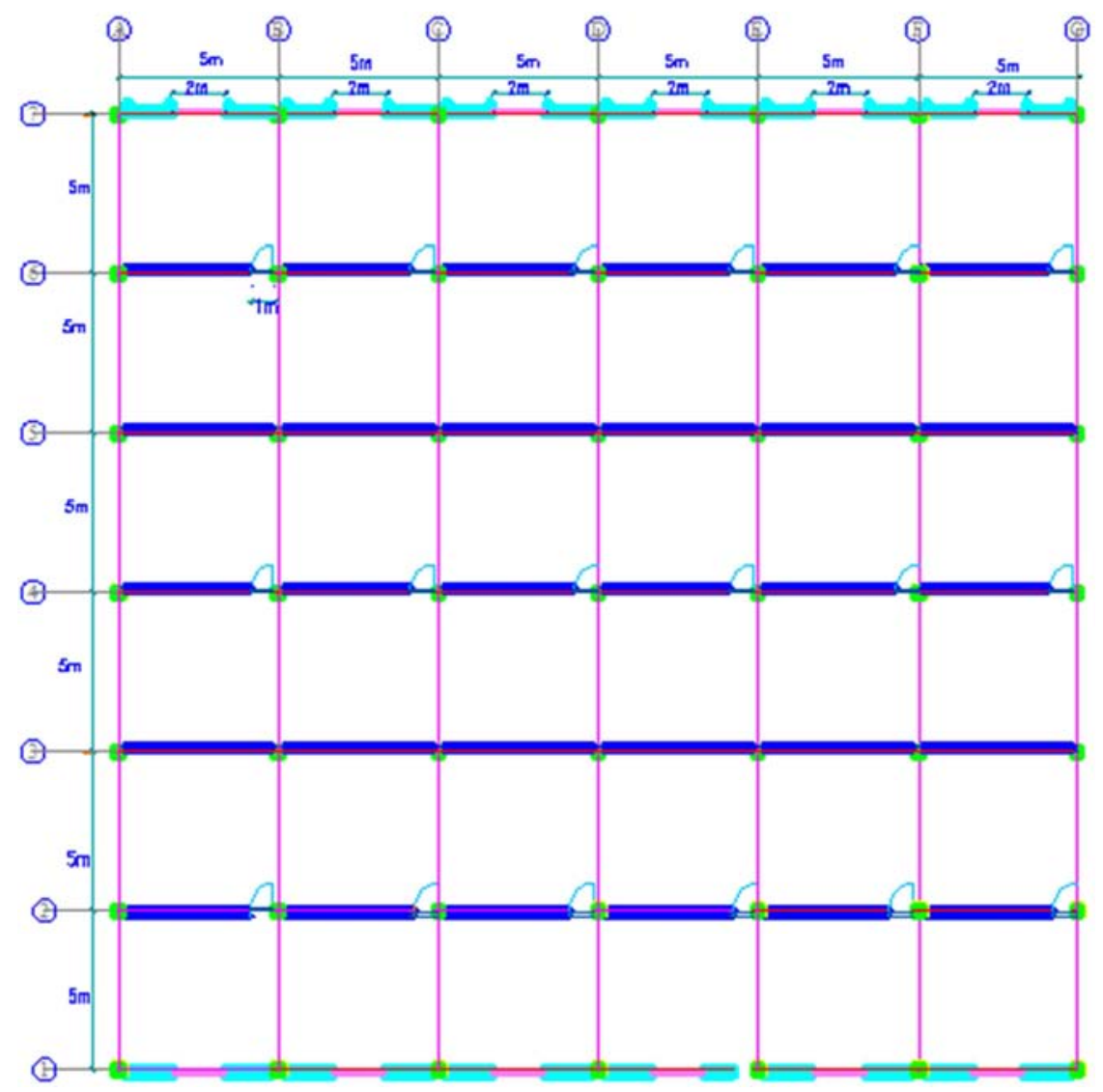

Figure 6. Plan view of Model 5 .

\subsection{Modeling of Masonry Infill}

In the case of an infill wall located in a lateral load resisting frame the stiffness and strength contribution of the infill are considered by modelling the infill as an equivalent compression strut (Smith [3]).

Because of its simplicity, several investigators have recommended the equivalent strut concept. In the present analysis, a trussed frame model is considered. This type of model does not neglect the bending moment in beams and columns. Rigid joints connect the beams and columns, but pin joints at the beam-to-column Junctions connect the equivalent struts.

Infill parameters (effective width, elastic modulus and strength) are calculated using the method recommended by Smith [3]. The length of the strut is given by the diagonal distance D of the panel (Figure 7) and its thickness is given by the thickness of the infill wall. The estimation of width $w$ of the strut is given below. The initial elastic modulus of the strut Ei is equated to Em the elastic modulus of masonry. As per UBC (1997), Em is given as $750 \mathrm{fm}$, where $\mathrm{fm}$ is the compressive stress of masonry in $\mathrm{MPa}$. The effective width was found to depend on the relative stiffness of the infill to the frame, the magnitude of the diagonal load and the aspect ratio of the infilled panel.

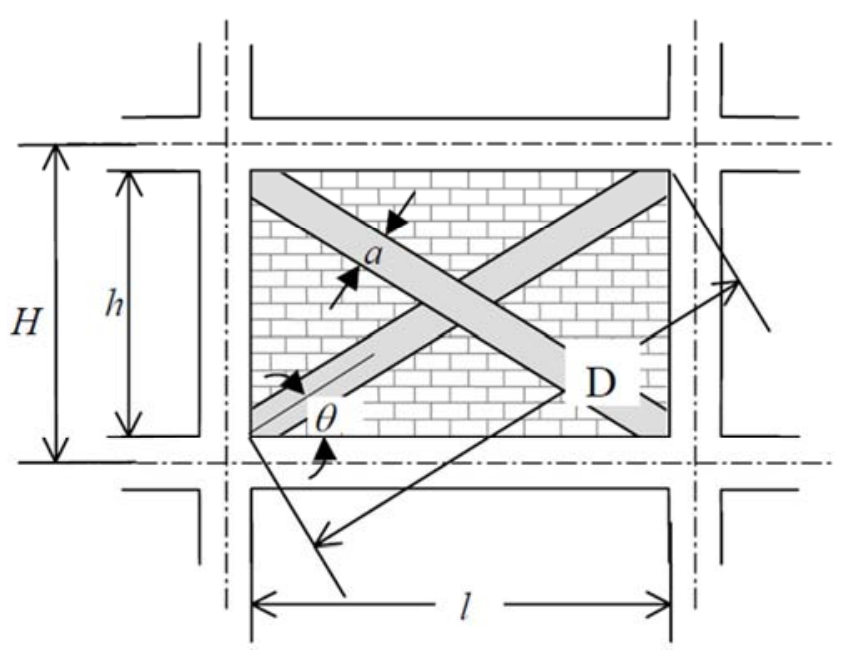

Figure 7. Strut geometry (Ghassan Al-Chaar).

The equivalent strut width, a, depends on the relative flexural stiffness of the infill to that of the columns of the confining frame. The relative infill to frame stiffness shall be evaluated using equation 1 (Stafford-Smith and Carter 1969) [2]:

$$
\lambda_{1}=\sqrt[4]{\frac{E_{m} t \sin 2 \theta}{4 E_{c} I_{\text {col }} h}}
$$


Using this expression, Mainstone (1971) [4] considers the relative infill to frame flexibility in the evaluation of the equivalent strut width of the panel as shown in equation 2

$$
a=0.175 D\left(\lambda_{1} H\right)^{-0.4}
$$

Where:

$$
\begin{aligned}
& \lambda_{1}=\text { Relative infill to frame stiffness parameter } \\
& a=\text { Equivalent width of infill strut, } \mathrm{cm} \\
& E_{m}=\text { modulus of elasticity of masonry infill, } M P a \\
& E_{c}=\text { modulus of elasticity of confining frame, } M P a \\
& I_{\text {column }}=\text { moment of inertia of masonry infill, } \mathrm{cm}^{4} \\
& t=\text { Gross thickness of the infill, } \mathrm{cm} \\
& h=\text { height of the infill panel, } \mathrm{cm} \\
& \theta=\text { Angle of the concentric equivalent strut, radians } \\
& D=\text { Diagonal length of infill, cm } \\
& H=\text { Height of the confining frame, } \mathrm{cm}
\end{aligned}
$$

\subsection{Eccentricity of Equivalent Strut}

The equivalent masonry strut is to be connected to the frame members as depicted in Figure 8. The infill forces are assumed to be mainly resisted by the columns, and the struts are placed accordingly. The strut should be pin-connected to the column at a distance lcolumn from the face of the beam. This distance is defined in Equations 3 and 4 and is calculated using the strut width, $a$.

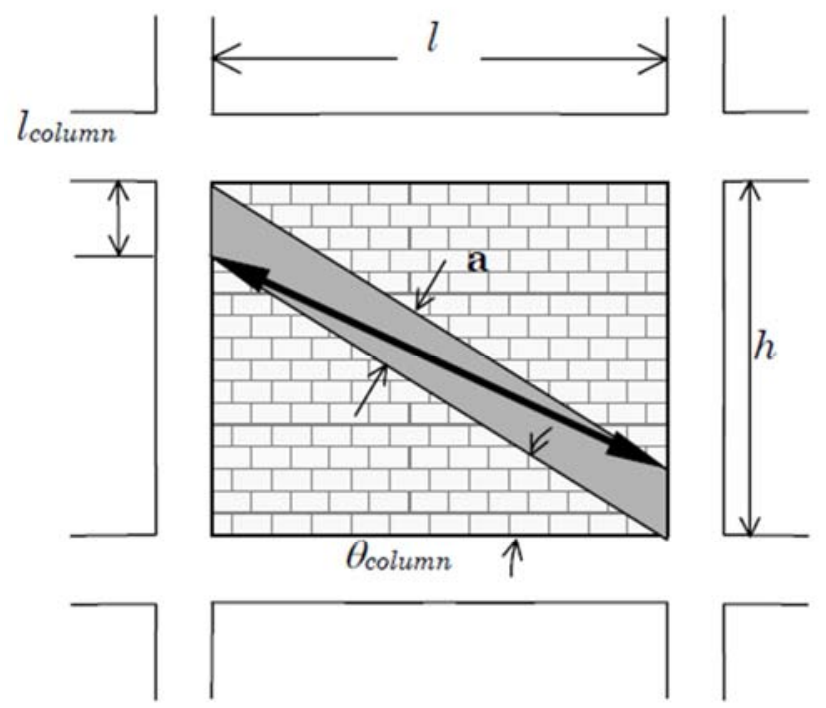

Figure 8. Placement of strut (Ghassan Al-Chaar).

$$
\begin{aligned}
& l_{\text {column }}=\frac{a}{\cos \theta_{\text {colun }}} \\
& \tan \theta_{\text {column }}=\frac{h-\frac{a}{\cos \theta_{\text {colun }}}}{l}
\end{aligned}
$$

\subsection{Plastic Hinge Placement}

Plastic hinges in columns should capture the interaction between axial load and moment capacity. These hinges should be located at a minimum distance $1_{\text {column }}$ from the face of the beam as shown in figure 9. Hinges in beams need only characterize the flexural behavior of the member.

These hinges should be placed at a minimum distance $l_{\text {beam }}$ from the face of the column. This distance is calculated from Equations 5 and 6 where $\theta_{\text {beam }}$ is the angle at which the infill forces would act if the eccentricity of the equivalent strut was assumed to act on the beam as depicted in Figure 9.

$$
\begin{aligned}
& l_{\text {beam }}=\frac{a}{\sin \theta_{\text {beam }}} \\
& \tan \theta_{\text {beam }}=\frac{h}{l-\frac{a}{\sin \theta_{\text {beam }}}}
\end{aligned}
$$
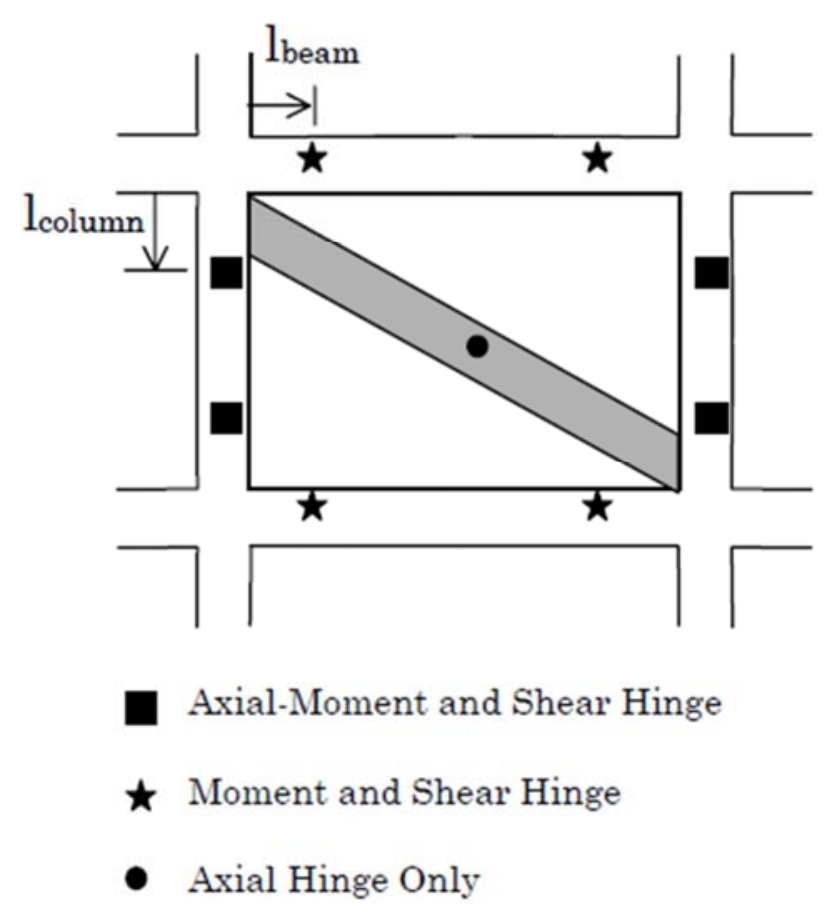

Figure 9. Plastic hinge placement (Ghassan Al-Chaar).

\subsection{Analysis of the Building Models}

The non-structural elements and components that do not significantly influence the building behavior were not modeled. The floor slabs are assumed to act as diaphragms, which ensure integral action of all the vertical lateral load-resisting elements. Beams and columns were modeled as frame elements with the centerlines joined at nodes. Rigid offsets were provided from the nodes to the faces of the columns or beams. The stiffness for columns and beams were taken as $0.7 E_{c} I g, 0.35 \mathrm{E}_{\mathrm{c}} \mathrm{Ig}$ respectively accounting for the cracking in the members and the contribution of flanges in the beams.

The weight of the slab was distributed to the surrounding beams as per ESEN1992:2015[21]. The mass of the slab was lumped at the Centre of mass location at each floor level. This was located at the design eccentricity from the calculated centre of stiffness. Design lateral forces at each storey level were applied at the Centre of mass locations independently in two horizontal directions ( $X$ - and $Y$ - directions).

Staircases and water tanks were not modeled for their stiffness but their masses were considered in the static and 
dynamic analyses. The design spectrum for hard soil as specified in ESEN1998:2015 [19] was used for the analysis. The effect of soil-structure interaction was ignored in the analyses. The columns were assumed to be fixed at the level of the bottom of the base slabs of respective isolated footings.

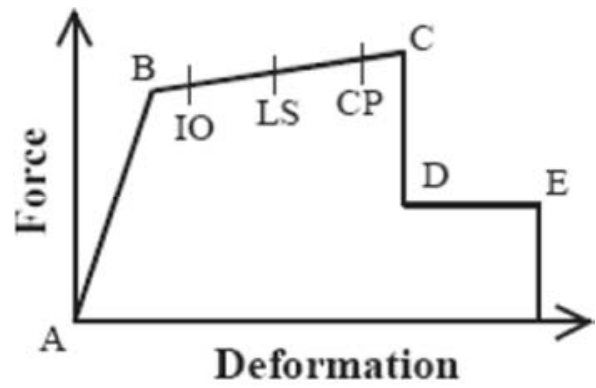

Figure 10. Force-Deformation Relation for Plastic Hinge in Pushover Analysis (Habibullah. et al., 1998).

\section{Analysis Results and Discussions}

The results of pushover analysis of reinforced concrete frame with different configuration of masonry wall are presented. Analysis of the models under the static and dynamic loads has been performed using Etabs 2015 software. All required data are provided in software and analyzed for total five models to get the result in terms of Base shear vs monitored roof displacement, Storey shear, story displacement and Element force. Subsequently these results are compared for reinforced concrete frame with different configuration of masonry wall.

\subsection{Base Shear vs Monitored Roof Displacement Curve}

Based up on the Displacement coefficient method of ASCE 41-13 [24] all the five building models are analyzed in ETABS 2015 standard structural software and the static pushover curve is generated as shown in figure 11 .

The presence of the infill wall both strengthens and stiffens the system, as illustrated in figure 11. For the case study building, the fully-infilled frame has approximately 3 times larger intial stiffness and 1.5 times greater peak strength than the bare frame. In figure 11, the first drop in strength for the fully and partially-infilled frame is due to the brittle failure of masonry materials initiating in the first-story infill walls. This behavior after first-story wall failure is due to wall-frame interaction and depends on the relative strength of the infill and framing.

So, based on these results, infill walls can be beneficial as long as they are properly taken into consideration in the design process and the failure mechanism is controlled.

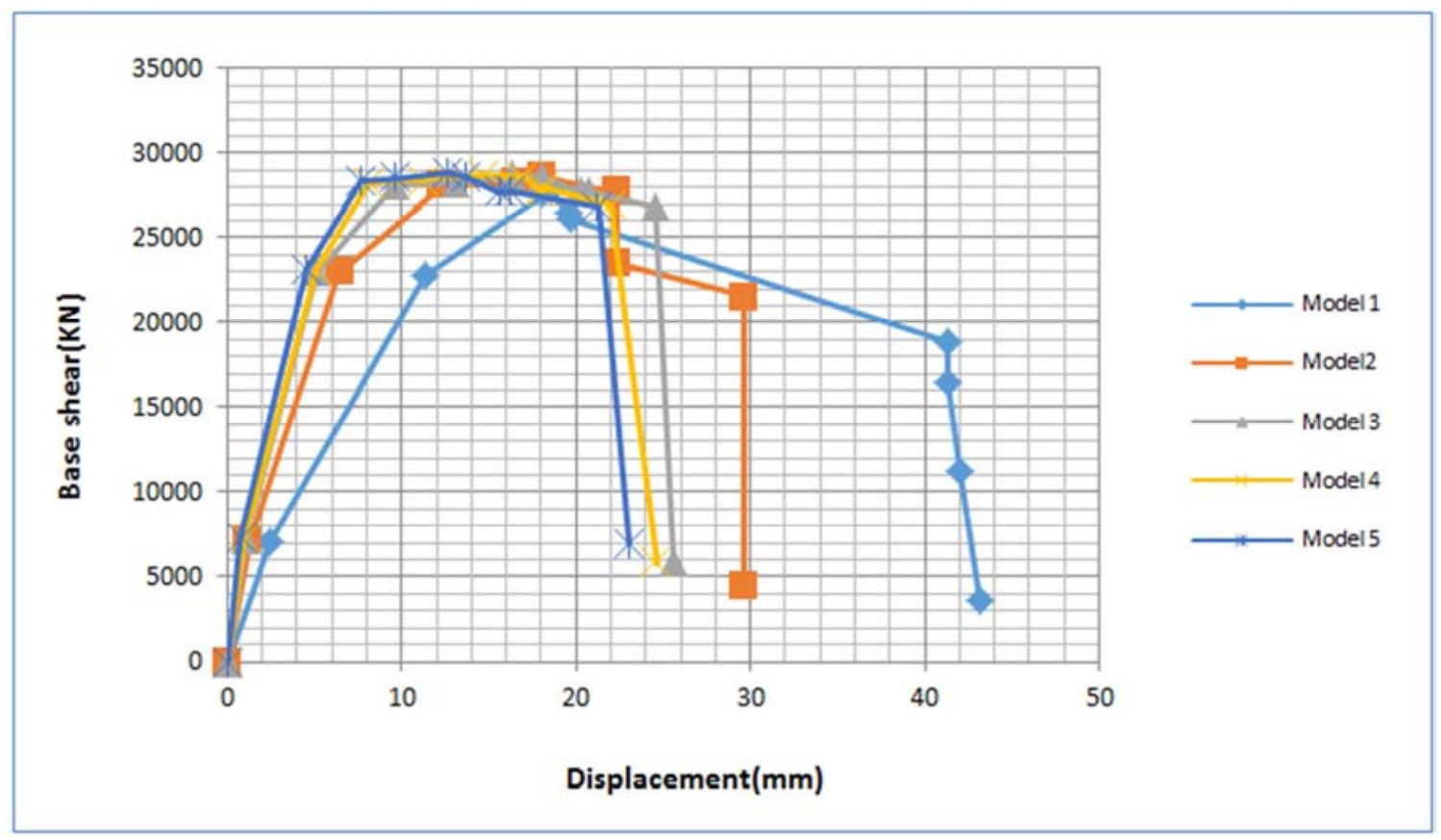

Figure 11. Pushover analysis result for 10-story RC building.

\subsection{Story Displacement for Different Models}

Figure 12. shows the comparative study of seismic demand in terms of lateral story displacement amongst all the five types of reinforced concrete frame with different configuration of infill. The lateral displacement obtained from the bare frame model is the maximum which is about $60 \%$ greater than that of fully infilled frame, nearly $50 \%$ greater than that of frame with $25 \%$ of the masonry wall reduced, about $40 \%$ greater than that of frame with $50 \%$ of the masonry wall reduced and $30 \%$ greater than that of frame with $75 \%$ of the masonry wall reduced.

Thus, the infill panel reduces the seismic demand of reinforced concrete buildings. The lateral story displacement is dramatically reduced due to introduction of infill. This probably is the cause of building designed in conventional way behaving near elastically even during strong earthquake. 


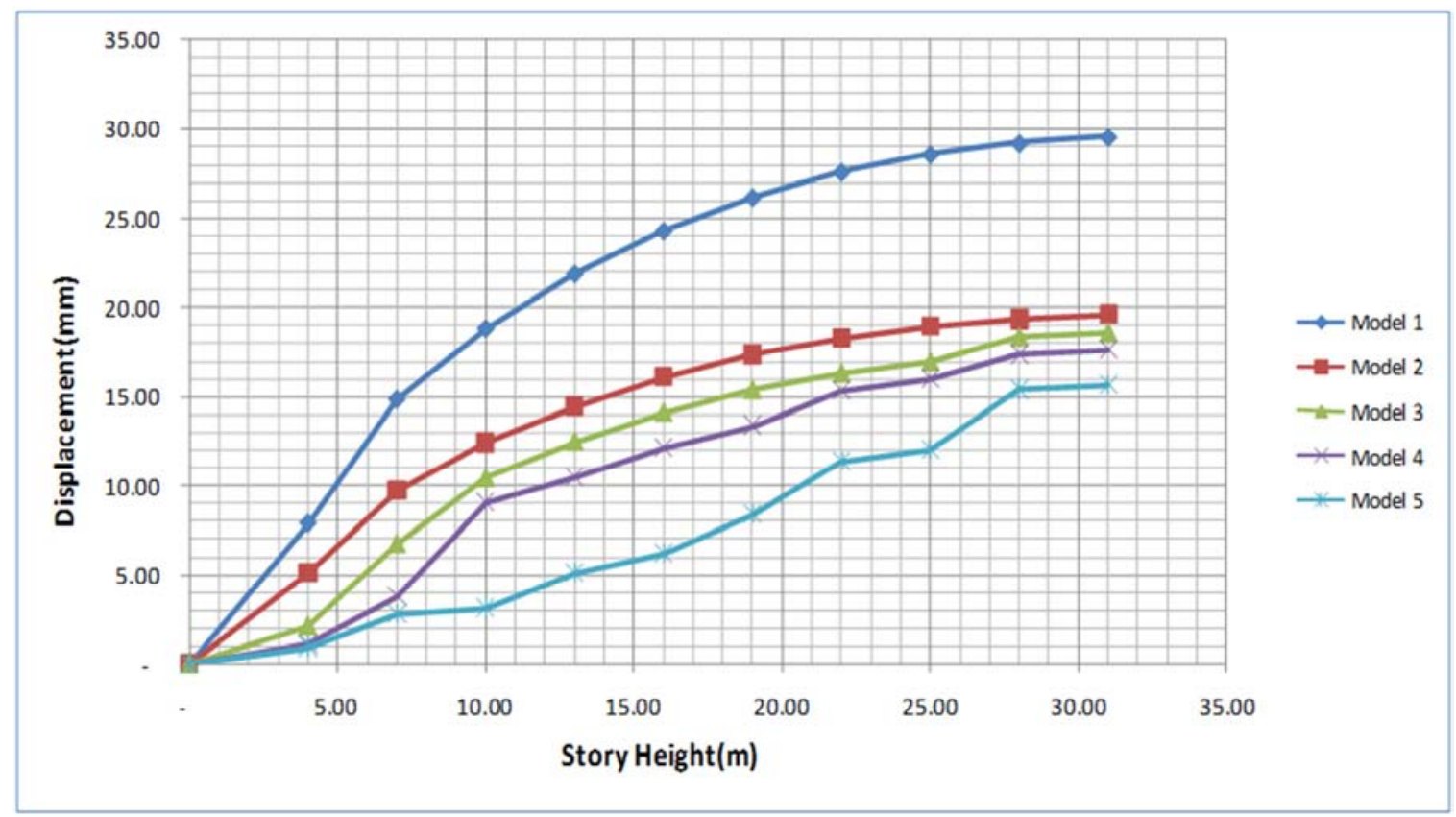

Figure 12. Comparison of Story displacements for different models.

\subsection{Member Forces}

In this project to understand the effect of different configuration of infill in reinforced concrete frame; study of the behavior of the column in all models for axial loads was conducted. Total of five nonlinear models are analyzed in ETABS 2015 and all models have same plan of building, therefore the position and label of columns are same in all plans of models which is shown in figure 2. After analysis consider the column no. $1(\mathrm{C} 1)$ shown in figure 2 . from all models for pushover load case and get the axial forces of column at performance point at every story from software, which is given in table 1 and the values for each model is compared with the bare frame model.

From this observation, it is evident that when an infilled frame is loaded laterally, the columns take the majority of the force and shear force exerted on the frame by the infill which is modeled as the eccentric equivalent struts. Generally, the relative increase of axial force is observed when the percentage of infill in reinforced concrete frame increases. It is observed that fully infilled reinforced concrete frame showed around $10 \%$ increase in axial force relative to bare frame model. The other infill models showed a lesser increase. The effect of infill on columns is to increase the shear force and to reduce bending moments.

In general compared to bare frame model, the infilled models predicted higher axial and shear forces in columns but lower bending moments in both beams and columns. Thus, the effect of infill panel is to change the predominantly a frame action of a moment resisting frame system towards truss action.

Table 1. Comparison of axial force for different models. (KN)

\begin{tabular}{|c|c|c|c|c|c|c|}
\hline Story & Elevation (m) & Model 1 & Model 2 & Model 3 & Model 4 & Model 5 \\
\hline Story 10 & 31 & 161 & 168 & 170 & 180 & 192 \\
\hline Story 9 & 28 & 444 & 454 & 459 & 470 & 488 \\
\hline Story 8 & 25 & 728 & 740 & 748 & 763 & 780 \\
\hline Story 7 & 22 & 1011 & 1025 & 1035 & 1052 & 1070 \\
\hline Story 6 & 19 & 1290 & 1309 & 1320 & 1340 & 1358 \\
\hline Story 5 & 16 & 1569 & 1589 & 1605 & 1628 & 1646 \\
\hline Story 4 & 13 & 1842 & 1865 & 1882 & 1907 & 1927 \\
\hline Story 2 & 7 & 2384 & 2412 & 2435 & 2467 & 2485 \\
\hline Story 1 & 4 & 2577 & 2608 & 2635 & 2662 & 2682 \\
\hline
\end{tabular}

\subsection{Story Shear}

Story shear is the total horizontal seismic shear force at the base of structure. Results from static pushover analysis at performance point for the case study buildings are shown in figure 13 .
As observed from the figure 13 the story shear calculated on the basis of bare frame model gave a lesser value than the other infilled frames; It was observed that the story shear in fully infilled frame is nearly $15 \%$ greater compared to bare frame model and frame with $25 \%$ of the masonry wall reduced was nearly $10 \%$ greater compared to the bare frame, frame 
with $50 \%$ of the masonry wall reduced is nearly $8 \%$ greater compared to the bare frame and frame with $75 \%$ of the masonry wall reduced is about $5 \%$ greater compared to the bare frame.

Since the bare frame models do not take in to account the stiffness rendered by the infill panel, it gives significantly longer time period. And hence smaller lateral forces. And when the infill is modeled, the structure becomes much stiffer than the bare frame model. Therefore, it has been found that calculation of earthquake forces by treating $\mathrm{RC}$ frames as ordinary frames without regards to infill leads to underestimation of base shear. This is because of bare frame is having larger value of fundamental natural time period as compared to other models due to absence of masonry infill walls. Fundamental natural period get increased and therefore base shear get reduced.

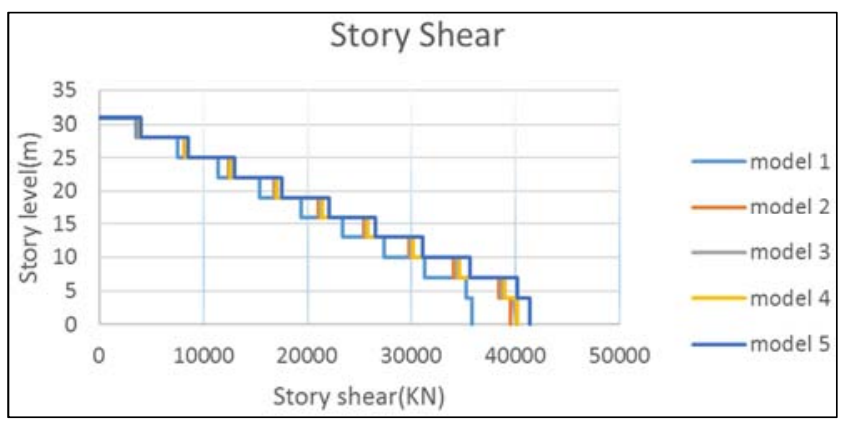

Figure 13. Comparison of story shear for different model.

\section{Conclusions}

From above results it is clear that pushover curve show an increase in initial stiffness, strength, and energy dissipation of the infilled frame, compared to the bare frame, despite the wall's brittle failure modes.

Due to the introduction of infill the displacement capacity decreases as depicted from the displacement profile (Figure 12). The lateral displacement obtained from the bare frame model is the maximum which is about $60 \%$ greater than that of infilled frame.

The presence of masonry walls is to change a frame action of a moment resisting frame structure towards a truss action. When infills are present, shear and axial force demands are considerably higher leaving the beam or column vulnerable to shear failure. The axial force and shear force of the bare frame is less than that of the infilled frame. Columns take the majority of the forces exerted on the frame by the infill because the eccentrically modeled equivalent struts transfers the axial load and shear force transferred from the action of lateral loads directly to the columns.

The story shear calculated on the basis of bare frame model gave a lesser value than the other infilled frames. It was observed that fully infilled frame is nearly $15 \%$ greater compared to bare frame model; frame with $25 \%$ of the masonry wall reduced was nearly $10 \%$ greater compared to the bare frame; frame with $50 \%$ of the masonry wall reduced is nearly $8 \%$ greater compared to the bare frame and frame with $75 \%$ of the masonry wall reduced is about $5 \%$ greater compared to the bare frame. This is because the bare frame models do not takes in to account the stiffness rendered by the infill panel, it gives significantly longer time period.

\section{References}

[1] Polyakov, S. V., 1960. On the interaction between masonry filler walls and enclosing frame when loaded in the plane of the wall, Translations in earthquake Engineering. EERI, San Francisco, 36-42.

[2] Stafford-Smith, B., and Carter, C., 1969. A method for the analysis of infilled frames, Proc, nst. Civ. Engrs, 44, 31-48.

[3] Stafford-Smith, B., 1962. Lateral stiffness of infilled frames, J. Struct. Div, 88 (6), 183-199.

[4] Mainstone, R. J., 1971. On the stiffness and strength of infilled frames, Proc, Inst. Civ. Engrs, Supplement IV, 57-90 (paper 7360S).

[5] Klingner, R. E., and Bertero, V. V. Earthquake resistance of infilled frames, Journal of structural Devision, ASCE, vol 104, NO. ST6, 1978, pp. 973-989.

[6] Holmes M. Steel frames with brickwork and concrete infilling. Proceedings of the Institution of Civil Engineers 19, 1961.

[7] Dhanasekar, M., Page, A. W., 1986. The influence of brick masonry infill properties on the behavior of infilled frames, Proc, Inst. Civ. Engrs, London, 81, $593-605$.

[8] A. K. Chopra, Dynamics of Structures, Prentice Hall, Englewood Cliffs, NJ, USA, 1995.

[9] Catherin Jeselia M., Modeling of Masonry infills, American Journal of Engineering, 2013.

[10] ETABS, User Interface Reference Manual. 2002, Computers \& Structures (CSi): California.

[11] American Society of Civil Engineers, ASCE-41: Seismic Rehabilitation of Existing Buildings. 2006: Virginia.

[12] Federal Emergency Management Agency, FEMA-356: Pre-standard and Commentary for the Seismic Rehabilitation of Buildings. 2000: Washington DC.

[13] Applied Technology Council, ATC-40: Seismic Evaluation and Retrofit of Concrete buildings. 1996: California.

[14] Ghassan Al-Chaar, Evaluating Strength and Stiffness of Unreinforced Masonry Infill Structures. 2002: US army corps of Engineers.

[15] M. Selim Gunay, A practical Guide to Nonlinear static analysis of reinforced concrete buildings with masonry infill walls, University of California, Berkeley.

[16] Mohammad H. Jinya V. R. Patel, Analysis Of Rc Frame With And Without Masonry Infill Wall With Different Stiffness With Outer Central Opening: International Journal of Research in Engineering and Technology, 2014.

[17] W. Axleyand V. V. Bertero, Infill Panels: Their Influence on Seismic Response of Buildings, EERC, University of California, Berkeley, CA, Rep. UCB/EERC-79/28.1969 
[18] ESEN1998: 2015, Design of Structures for Earthquake Resistance. Ethiopian Building Code Standard prepared by Ministry of Works and Urban Development. Addis Ababa, Ethiopia.

[19] Asteris et al, P. G. and Tzamtzis, A. D., 2003. "On the Use of a Regular Yield Surface for the Analysis of Unreinforced Masonry Walls". Electronic Journal of Structural Engineering.

[20] ESEN1992: 2015, Design of Concrete Structures. Ethiopian Building Code Standard prepared by Ministry of Works and Urban Development. Addis Ababa, Ethiopia.

[21] ESEN1996: 2015, Design of Masonry Structures. Ethiopian Building Code Standard prepared by Ministry of Works and Urban Development. Addis Ababa, Ethiopia.

[22] EN1998-1-1:2005, Euro code 8: Design of structures for earthquake.

[23] T. Paulay and M. Priestley, Seismic Design of Reinforced Concrete and Masonry Buildings. New York: Jhon Wiley \& Sons, 1992.

[24] ESEN1991: 2015,--Basis of design and actions on structure Ethiopian Building Code Standard prepared by Ministry of Works and Urban Development. Addis Ababa, Ethiopia.

[25] FEMA 273, NEHRP Commentary on the Guidelines for the Seismic Rehabilitation of Buildings, FEMA, October 1997.
[26] FEMA 306, "Evaluation of Earthquake Damaged Concrete and Masonry Wall Buildings: Basic Procedures Manual," Federal Emergency Management Agency, 1998.

[27] FEMA 310, Handbook for the Seismic Evaluation of Buildings - A Prestandard, FEMA, January 1998.

[28] Patnala VS Neelima, Ramancharla Pradeep Kumar, Seismic Behavior of RC Frame with URM Infill: Case Study, International Journal of Education and Applied Research (IJEAR), Vol. 4, Issue Spl-2, Jan-June 2014.

[29] D. B. Karwar and Dr. R. S. Londhe (2014), Performance of RC Framed Structure by Using Pushover Analysis, International Journal of Emerging Technology and Advanced Engineering.

[30] Vikas Govalkar, P. J. Salunke, N. G. Gore(2014), Analysis of Bare Frame and Infilled Frame with Different Position of Shear Wall, International Journal of Recent Technology and Engineering (IJRTE), 2277-3878.

[31] S. Niruba, K. V. Boobalakrishnan, and K. M. Gopalakrishnan (2014), Analysis of Masonry Infill In A Multi-Storied Building, International Refereed Journal of Engineering and Science, 2319-1821(3), 26-31.

[32] Mohammad H. Jinya and V. R. Patel(2014), ANALYSIS OF RC FRAME WITH AND WITHOUT MASONRY INFILL WALL WITH DIFFERENT STIFFNESS WITH OUTER CENTRAL OPENING, International Journal of Research in Engineering and Technology, 2319-1163(3), 2321-7308. 